\title{
Depression and Anxiety among University Students: A Comparison between COVID-19 Pandemic Panic Period and Post-panic Period in Bangladesh
}

\author{
Gowranga Paul ${ }^{1}$ (D), Mohammad Meshbahur Rahman ${ }^{2,3 *}$ (D), Shayla Naznin ${ }^{4}$ (D), Mashfiqul Chowdhury ${ }^{5}$, \\ Md Jamal Uddin ${ }^{6}$ (D)
}

${ }^{1}$ Department of Statistics, Mawlana Bhashani Science and Technology University, Santosh, Tangail, Bangladesh; ${ }^{2}$ Department of Biostatistics, National Institute of Preventive and Social Medicine, Dhaka, Bangladesh; ${ }^{3}$ Department of Digital Health, Biomedical Research Foundation, Dhaka, Bangladesh; ${ }^{4}$ Department of Statistics, Mawlana Bhashani Science and Technology University, Santosh, Tangail, Bangladesh; ${ }^{5}$ Department of Statistics, Mawlana Bhashani Science and Technology University, Santosh, Tangail, Bangladesh; ${ }^{6}$ Department of Statistics, Shahjalal University of Science and Technology, Sylhet, Bangladesh

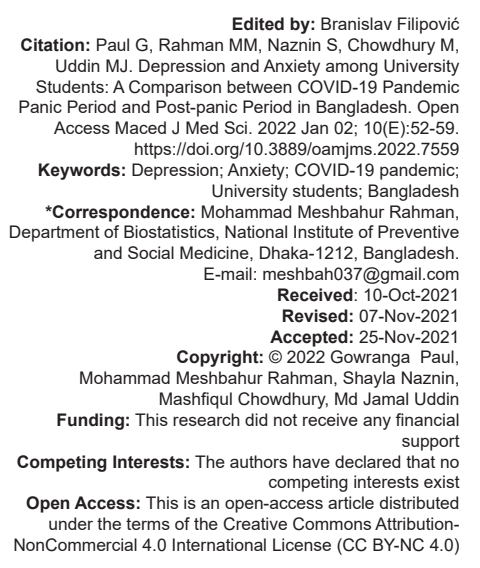

Introduction

The acute respiratory syndrome coronavirus 2 (SARS-Cov-2) detected in Wuhan, Hubei Province, caused the emergence of novel coronavirus disease 2019, referred to as COVID-19 [1], [2], [3]. In response to this dire situation, the World Health Organization (WHO) declared a global pandemic on March 11, 2020 [4]. The pandemic has rapidly spread around the world and created a global public health threads. The pandemic prompted the implementation of emergency health protocols to control the spread of the infection, many of which included a series of lockdowns with home quarantine, social distancing, wearing face masks, travel restrictions, and the closure of academic institutions and government organizations [5], [6], [7]. As a result, it caused widespread public distress as well as widespread fear and panic, particularly among students [8], [9].

Due to the unprecedented experience of "home quarantine" under lockdown with uncertainty of academic and professional career, the university students of Bangladesh have multifaceted impacts on their mental health [8]. In the normal situation, several previous studies stated that a large number of university students, particularly, senior students, were experiencing moderate to severely depression and anxiety, which has a negative impact on their daily activities [9], [10], [11], [12]. However, in the current COVID-19 pandemic, the depression and anxiety problems were more triggered in university students [8], [9], [13], [14]. Furthermore, the ongoing pandemic has created a psycho-emotional panic situation, with countries reporting an alarming spread 
of the virus, which has increased the risk of suicidal behavior [15], [16].

In Bangladesh, the rapid spread of the virus created a panic situation among the citizen at early stage of the pandemic (March-July 2020). The frighten situation reduced later and all organizations are coming back to their regular activities except educational institutions [17], [18], [19]. Since the educational institution was closed for long time, the students had to face different embarrassing conditions in their family as well as the society. Specially, university students suffer more because they were in their last stage of their education and their family is eagerly waiting to their financial support. That's why, learning on the psycho-emotional changes among university students is important which is not yet sufficiently investigated. Given the circumstances, we aimed to assess the university student's psycho-emotional changes through investigating their level of depression and anxiety effects during panic and post-panic period of COVID-19 pandemic in Bangladesh.

\section{Methods}

\section{Study design and data collection}

A cross-sectional online survey was conducted among the university students in Bangladesh using a Google Form questionnaire. In Bangladesh, COVID19 infection was first detected on March 8, 2020 and the infection was getting viral gradually experiencing double consecutively within a short time [3]. Due to rapid transmission of the infection, the people were suffering from massive fear which created a panic period and stayed up to July 2020 . Then, the pandemic panic started reducing due to low detection rate of daily confirmed new cases and deaths [18], [19], and daily case detections on 13 July decreased by $30.7 \%$ in comparison to previous week, reported by the WHO [17]. The survey was conducted to collect information in both panic period (April to July, 2020) and post-panic period (August to November, 2020). For panic period, the data were collected in July, 2020 and for post-panic period the data were collected in November, 2020.

University students from various divisions in Bangladesh were contacted through different social networks. Three hundred and sixty university students (175 from panic period and 185 from post-panic period) were responded to this survey and their sociodemographic, depression and anxiety related information were collected. Among the 360 students, 20 ( 05 from panic period and 15 from post-panic period) students responded the questionnaire incompletely and their responses were excluded from the analysis. Finally, 340 samples (170 from panic period and 170

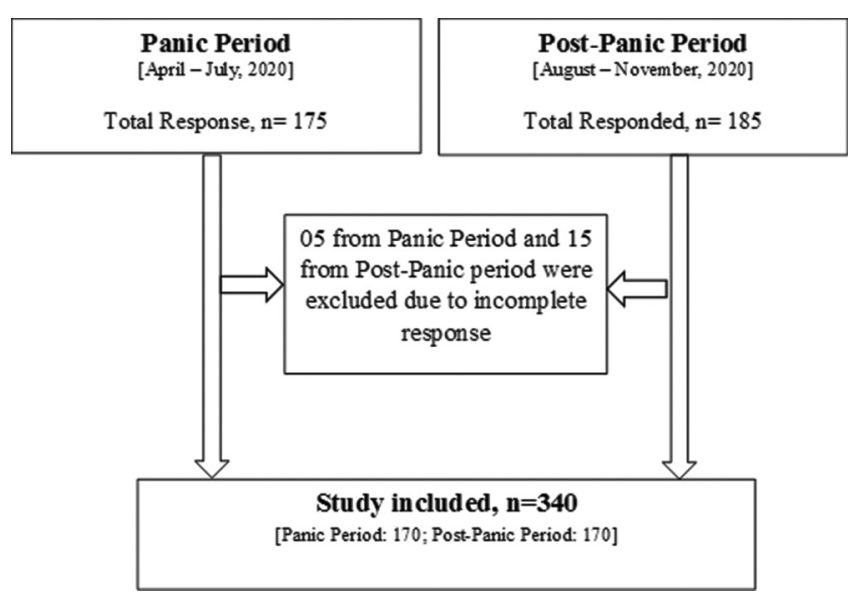

Figure 1: Sampling design of the study

from post-panic period) were included in the data analysis. The details data sampling design is presented in the Figure 1.

\section{Measures}

A semi-structured and self-reported e-questionnaire containing informed consent, questions regarding sociodemographics, depression and anxiety were used.

\section{Sociodemographic information}

'Sociodemographic information included age ("17-21;" "21-26" years), gender ("male;" "female”), family types ("nuclear;" "joint/extended"), place of residence ("rural;" "urban"), education ("first-third;" "fourth and higher years"), family economic condition ("lower class;" "lower middle class;" "middle and upper class"), family head's occupation ("unemployed;" "agriculture/labor work;" "business;" "service"), and family earning members ("none;" "one;" "two and more").

\section{Outcome variables}

Depression and anxiety were the two outcome variables to assess psycho-emotional changes of the university students. Respondent's depression was determined using Patient Health Questionnaire (PHQ-9) [20]. PHQ-9 is a well-established and simple questionnaire for screening depression of an individual and what state he/she is in during the survey. The codes for PHQ-9 questions are " $0=$ not at all" to "3 = nearly every day." Using the PHQ-9 questionnaire, we calculated a score variable to measure the level of depression symptoms and later categorized as: score $<10$ for absence of depression symptoms and score $\geq 10$ for the presence of depression symptoms [20].

Student's anxiety was evaluated using the Generalized Anxiety Disorder (GAD-7) questionnaire, 
the questions were used for screening anxiety state of the students on a scale starting from " $0=$ no at all sure" to "3 = nearly every day" [20]. GAD-7 has been found successful in identifying anxiety among different populations and thus used for its reliability. The overall level of anxiety was computed and categorized as: score $<10$ for absence of anxiety symptoms and score $\geq 10$ for the presence of anxiety symptoms [20]. The coding and scaling were evident for both the cases. The detail list of questions and scaling used in PHQ-9 and GAD-7 questionnaires were tabulated in Table 1.

Table 1: PHQ-9 and GAD-7 questionnaire with their classifications

\begin{tabular}{|c|c|c|c|}
\hline $\begin{array}{l}\text { Question } \\
\text { number }\end{array}$ & PHQ-9 questions & & GAD-7 Questions \\
\hline 01 & $\begin{array}{l}\text { Little interest or pleasure in doing } \\
\text { things }\end{array}$ & 01 & $\begin{array}{l}\text { Feeling nervous, anxious, or } \\
\text { on edge }\end{array}$ \\
\hline 02 & Feeling down, depressed, or hopeless & 02 & $\begin{array}{l}\text { Not being able to stop or control } \\
\text { worrying }\end{array}$ \\
\hline 03 & $\begin{array}{l}\text { Trouble falling or staying asleep, or } \\
\text { sleeping too much }\end{array}$ & 03 & $\begin{array}{l}\text { Worrying too much about } \\
\text { different things }\end{array}$ \\
\hline 04 & Feeling tired or having little energy & 04 & Trouble relaxing \\
\hline 05 & Poor appetite or overeating & 05 & $\begin{array}{l}\text { Being so restless that it is hard } \\
\text { to sit still }\end{array}$ \\
\hline 06 & $\begin{array}{l}\text { Feeling bad about yourself - or that } \\
\text { you are a failure or have let yourself or } \\
\text { your family down }\end{array}$ & 06 & $\begin{array}{l}\text { Becoming easily annoyed or } \\
\text { irritable }\end{array}$ \\
\hline 07 & $\begin{array}{l}\text { Trouble concentrating on things, such } \\
\text { as reading the newspaper or watching } \\
\text { television }\end{array}$ & 07 & $\begin{array}{l}\text { Feeling afraid, as if something } \\
\text { awful might happen }\end{array}$ \\
\hline 08 & $\begin{array}{l}\text { Moving or speaking so slowly that } \\
\text { other people could have noticed }\end{array}$ & & \\
\hline 09 & $\begin{array}{l}\text { Thoughts that you would be better off } \\
\text { dead, or of hurting yourself }\end{array}$ & & \\
\hline
\end{tabular}

Reliability and validity of the data were ensured using a number of techniques: (1) Apply SPSS 23.0 in data analysis; (2) explore descriptive statistics; (3) reliability analyses of the variables used in calculating student's depression and anxiety (Cronbach's alpha, the reliability coefficient values for the variables used in depression and anxiety were found 0.77 and 0.84 , respectively) and (4) use of two statistical techniques, namely Chi-square test and logistic regression [21], [22], [23].

\section{Statistical analysis}

To discover the respondent's sociodemographic characteristics, frequency distribution were used and depression/anxiety status were summarized through bar diagram. Chi-square test was used as the univariate analysis to determine the joint frequency as well as association of "depression" and "anxiety" with socio-demographic characteristics. Student's t-test were performed to check the significant difference of depression and anxiety according to between two period (panic versus post-panic period); male-female and urban-rural [21]. Unadjusted and adjusted odds ratio (OR) were observed [21], [22] using logistic regression analysis to identify the factors of depression and anxiety of the university students. To do this, the dependent variables (anxiety and depression) were categorized into two categories, that is, absence of depression/ anxiety symptoms (depression/anxiety score <10) and presence of depression/anxiety symptoms (depression/ anxiety score $\geq 10$ ). All the statistical analysis was performed using SPSS (version-23).

\section{Results}

Sociodemographic information of different selected variables of the university students in Bangladesh was presented in Table 2. All most two-third $(65.9 \%)$ of the students who participated in panic period were 22-26 years old whereas this percentage was $54.7 \%$ in post-panic period. Male students were more participated in the study in both panic and pre-panic periods (Male: $62.4 \%$ and $54.7 \%$ ). In the panic period, rural students responded more $(52.9 \%)$, while in the postpanic period, $57.1 \%$ of students were from urban areas. In panic period, $60.0 \%$ students were from middle- and upper-class family where this percentage was $67.1 \%$ in post-panic period. In both periods, the majority family head's occupation was service, and the maximum number of earning members was one (Table 2).

Table 2: Demographic profile of the students during COVID-19 panic and post-panic period ( $n=170$ for both panic and post-panic period)

\begin{tabular}{|c|c|c|}
\hline \multirow[t]{2}{*}{ Characteristics } & \multicolumn{2}{|l|}{ Time } \\
\hline & Panic period, $\mathrm{n}(\%)$ & Post-panic period, n (\%) \\
\hline \multicolumn{3}{|l|}{ Age } \\
\hline $17-21$ years & $58(34.1)$ & $77(45.3)$ \\
\hline $22-26$ years & $112(65.9)$ & $93(54.7)$ \\
\hline \multicolumn{3}{|l|}{ Gender } \\
\hline Male & $106(62.4)$ & $93(54.7)$ \\
\hline Female & $64(37.6)$ & $77(45.3)$ \\
\hline \multicolumn{3}{|l|}{ Family types } \\
\hline Nuclear & $90(52.9)$ & $86(50.6)$ \\
\hline Joint/Extended & $80(47.1)$ & $84(48.2)$ \\
\hline \multicolumn{3}{|l|}{ Place of residence } \\
\hline Rural & $90(52.9)$ & $73(42.9)$ \\
\hline Urban & $80(47.1)$ & $97(57.1)$ \\
\hline \multicolumn{3}{|c|}{ Family economic condition } \\
\hline Lower class & $14(8.2)$ & $8(4.7)$ \\
\hline Lower middle class & $54(31.8)$ & $48(28.2)$ \\
\hline $\begin{array}{l}\text { Middle and upper } \\
\text { class }\end{array}$ & $102(60.0)$ & $114(67.1)$ \\
\hline \multicolumn{3}{|c|}{ Family head's occupation } \\
\hline Unemployed & $20(12.3)$ & $22(13.8)$ \\
\hline Agriculture/Labor & $44(27.0)$ & $28(17.6)$ \\
\hline Business & 35 (21.5) & $37(23.3)$ \\
\hline Service & $64(39.3)$ & $72(45.3)$ \\
\hline \multicolumn{3}{|l|}{ Family earning members } \\
\hline None & $2(1.2)$ & $2(1.2)$ \\
\hline One & $124(72.9)$ & $119(70.0)$ \\
\hline Two and more & $44(25.9)$ & $49(28.8)$ \\
\hline
\end{tabular}

\section{Level of depression and anxiety symptoms during panic and post-panic periods}

Figure 2 represent the prevalence of depression and anxiety symptoms during panic and post-panic periods. In panic period, the proportion of depression symptoms was $49.4 \%$ where the proportion increased to $52.4 \%$ in the post-panic period. In case of anxiety symptoms, $38.2 \%$ students were experienced 


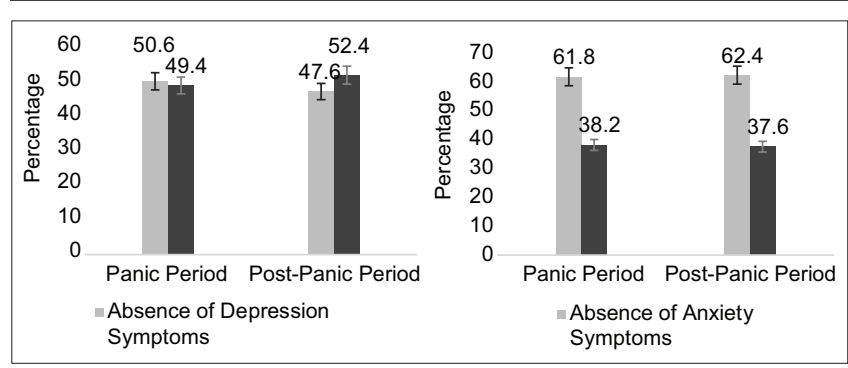

Figure 2: Depression and anxiety symptoms distribution during panic and post-panic periods

in anxiety symptoms during panic period where this proportion was almost similar in the post-panic period (Figure 2).

\section{Test of significance of depression and anxiety}

The significant difference of depression and anxiety between the two time periods (panic versus post-panic period) was examined through Student's t-test. We also showed the depression and anxiety difference according to respondent's gender and place of residence (Table 3 ). We found that the student's reported higher depression in post-panic period compared to panic period at $7 \%$ level of significant. Similarly, urban students were also experiencing significantly more depression and anxiety symptoms than their counterparts. Female students significantly reported more anxiety symptoms than the male $(p<0.01)$.

Table 3: Test of significance of the depression and anxiety symptoms among university students

\begin{tabular}{|c|c|c|c|c|}
\hline \multirow[t]{2}{*}{ Variables } & \multicolumn{2}{|l|}{ Depression } & \multicolumn{2}{|l|}{ Anxiety } \\
\hline & Mean $( \pm$ SD $)$ & $\mathrm{p}$-value & $\operatorname{Mean}( \pm \mathrm{SD})$ & $p$-value \\
\hline \multicolumn{5}{|l|}{ Period } \\
\hline Panic period & $9.50(5.10)$ & 0.070 & 8.38 (5.31) & 0.740 \\
\hline $\begin{array}{l}\text { Post-panic } \\
\text { period }\end{array}$ & $10.60(5.80)$ & & $8.58(5.06)$ & \\
\hline \multicolumn{5}{|l|}{ Gender } \\
\hline Male & $9.65(5.53)$ & 0.160 & $7.76(5.16)$ & 0.002 \\
\hline Female & $10.50(5.37)$ & & $9.49(5.05)$ & \\
\hline \multicolumn{5}{|c|}{ Place of residence } \\
\hline Rural & $9.05(5.11)$ & 0.020 & $7.36(4.68)$ & 0.0001 \\
\hline Urban & $10.89(5.66)$ & & $9.51(5.41)$ & \\
\hline
\end{tabular}

\section{Risk factors associated with depression and anxiety}

The Chi-square association test revealed that there was a significant relationship between student's depression and family types such that students with joint family $(53.8 \%)$ reported higher level of depression $(p<0.05)$. Students from urban areas (58.4\%) had a significant association with depression $(p<0.05)$ whereas age, gender, education, family head's occupation and family economic condition found no significant association with depression. Gender, on the other hand, had an association with anxiety $(p<0.01)$. The students, from urban area were reported significantly more $(p<0.01)$ anxiety symptoms than the rural students (Table 4 ).

\section{Degree of risk factors of student's depression and anxiety symptoms}

Table 5 shows the risk factors associated with student's depression and anxiety symptoms. Students aged 22-26 years were reported 1.52 times (95\% Cl: 0.82-2.78) more likely to be depressed and 1.43 times $(95 \% \mathrm{Cl}: 0.76-2.69)$ more likely to experience anxiety symptoms than students aged 17-21 years. The female students were reported less likely to be depressed than male students (OR: 0.89; 95\% Cl: 0.54-2.78). The students who were from joint family (OR: 1.75; 95\% Cl: 1.08-2.82), lived in urban area (OR: 1.99; 95\% Cl: 1.71-3.38), and came from lower middle-class families (OR: 1.26; 95\% $\mathrm{Cl}$ : 0.46-3.47) and whose family head was farmer or laborer (OR: 1.30; 95\% Cl:.56-3.07) were stated more likely to be depressed than their counterparts. Students in the post-panic period were stated 1.10 times $(95 \%$ $\mathrm{Cl}$ : 0.74-1.87) more likely to be depressed than those of the panic period. On the other hand, students from a joint family (OR: 1.82; 95\% Cl: 1.09-3.02) and living in an urban area (OR: 2.18; 95\% Cl: 1.24-3.83) were reported more likely to be experienced in anxiety symptoms than their counterparts (Table 5).

\section{Discussion}

In this study, we aimed to assess the university student's psycho-emotional changes through investigating their level of depression and anxiety effects during panic (April-July, 2020) and post-panic (August-November, 2020) periods of COVID-19 pandemic in Bangladesh. During both periods, we found that university students had a higher percentage of depression and anxiety symptoms. This high percentage of symptoms is comparable to some other studies conducted in Bangladesh [8], [9], [12].

Many studies from various countries also have assessed depression among the university students. For example, Rizvi and the authors reported $40.9 \%$ prevalence of depression among the students of Pakistan [24]. The other reported prevalence of depression were $37 \%$ in Malaysia, $43.7 \%$ in India, $68.5 \%$ in Hong Kong; $27.1 \%$ in Turkey, nearly fifty percent in Saudi Arabia, more than three quarter in Egypt, more than one fifth present in the USA and Australia [25], [26], [27], [28], [29], [30], [31], [32]. The anxietyrateswerereportedfiftypercentinTurkeyandHong Kong, more than a quarter in USAand Australia, and more ornearaboutthreequarterinPakistan, India, SaudiArabia, EgyptandMalaysia[25], [26], [27], [28], [29], [30], [31], [32].

However, the students in post-panic period were experiencing comparatively higher depression symptoms than the panic period which is a significance 
Table 4: Association between depressions, anxiety with different sociodemographic factors

\begin{tabular}{|c|c|c|c|c|c|c|}
\hline Variables & Absence of depression & Presence of depression & $p$-value & Absence of anxiety & Presence of anxiety & $p$-value \\
\hline \multicolumn{7}{|l|}{ Age } \\
\hline $17-21$ years & $69(41.3)$ & $66(38.2)$ & \multirow[t]{2}{*}{$p=0.551$} & $84(39.8)$ & $51(39.5)$ & \multirow[t]{2}{*}{$p=0.960$} \\
\hline $22-26$ years & $98(58.7)$ & $107(61.8)$ & & $127(60.2)$ & $78(60.5)$ & \\
\hline \multicolumn{7}{|l|}{ Gender } \\
\hline Male & $99(59.3)$ & $100(57.8)$ & \multirow[t]{2}{*}{$p=0.782$} & $137(64.9)$ & $62(48.1)$ & \multirow[t]{2}{*}{$p=0.002$} \\
\hline Female & $68(40.7)$ & $73(42.2)$ & & $74(35.1)$ & 67 (51.9) & \\
\hline \multicolumn{7}{|l|}{ Family types } \\
\hline Nuclear & $96(57.5)$ & $80(46.2)$ & \multirow[t]{2}{*}{$p=0.038$} & $116(55.0)$ & $60(46.5)$ & \multirow[t]{2}{*}{$p=0.130$} \\
\hline Joint/Extended & $71(42.5)$ & $93(53.8)$ & & $95(45.0)$ & 69 (53.9) & \\
\hline \multicolumn{7}{|l|}{ Place of residence } \\
\hline Rural & $91(54.5)$ & $72(41.6)$ & \multirow[t]{2}{*}{$p=0.018$} & $118(55.9)$ & $45(34.9)$ & \multirow[t]{2}{*}{$p=0.001$} \\
\hline Urban & $76(45.5)$ & $101(58.4)$ & & $93(44.1)$ & $84(65.1)$ & \\
\hline \multicolumn{7}{|c|}{ Family economic condition } \\
\hline Lower class & $11(6.4)$ & $11(6.6)$ & \multirow[t]{3}{*}{$p=0.884$} & $13(6.2)$ & $9(7.0)$ & \multirow[t]{3}{*}{$p=0.949$} \\
\hline Lower middle class & $48(28.7)$ & $54(31.2)$ & & $63(29.9)$ & 39 (30.9) & \\
\hline $\begin{array}{l}\text { Middle and upper } \\
\text { class }\end{array}$ & $108(64.7)$ & $108(62.4)$ & & $135(64.0)$ & $81(62.8)$ & \\
\hline \multicolumn{7}{|l|}{ Time period } \\
\hline Panic period & $86(51.5)$ & $84(48.6)$ & \multirow[t]{2}{*}{$p=0.588$} & $105(49.8)$ & $65(55.4)$ & \multirow[t]{2}{*}{$p=0.900$} \\
\hline Post-panic period & $81(48.5)$ & $89(51.4)$ & & $106(50.2)$ & $64(49.6)$ & \\
\hline \multicolumn{7}{|c|}{ Family head's occupation } \\
\hline Unemployed & $20(12.5)$ & $22(13.6)$ & \multirow[t]{4}{*}{$p=0.860$} & $26(12.9)$ & $16(13.2)$ & \multirow[t]{4}{*}{$p=0.174$} \\
\hline $\begin{array}{l}\text { Agriculture/Labor } \\
\text { works }\end{array}$ & $35(21.9)$ & $37(22.8)$ & & $52(25.9)$ & $20(16.5)$ & \\
\hline Business & $39(24.4)$ & $33(20.4)$ & & $46(22.9)$ & $26(21.5)$ & \\
\hline Service & $66(41.3)$ & $70(43.2)$ & & 77 (38.3) & $59(48.8)$ & \\
\hline
\end{tabular}

finding of our study. During the panic period, students were stay with their families and did not feel so much stressed because they believed that this situation was temporary and would be over soon. However, when the situation lasted longer, in post-panic period, many students' families faced financial difficulties due to job loss or lack of income, which had an indirect effect on students' mental health. Furthermore, many students manage their study costs through their own income such as giving tuition in normal situation, but due to the COVID-19 situation, almost all students staying with their family and have no income opportunity. As a result, students became more depressed and anxious during the post-panic period [33], [34].

Our study found that older students were more likely to be depressed and anxious than their counterparts which is very comparable to other studies [8], [9]. A study conducted on Malaysian university students reported that older students were significantly more vulnerable to the risk of both depression and anxiety symptoms [26]. Getting a secure job in developing country is more competitive due to the limited job sectors. Generally, older students have a higher tendency of getting jobs and they prepare himself for competitive job exams from $3^{\text {rd }}$ or $4^{\text {th }}$ years of their university life. The coronavirus pandemic is a big barrier of this issue because competitive job exams were postponed due to rapid spread of the virus. Moreover, many students had not taken part in the competitive job exams due to long time lockdown. In addition, the maximum age allowed for joining government jobs sectors in Bangladesh is 30 years, so the students are depressed and anxious about this issue as the countrywide long-time lockdown hampers them in joining the jobs. At the end of 2020 (post-panic period), the university students strike in several times for continuing incomplete exams as well as all academic activities so that they can apply for competitive job exams. Although the spread of COVID-19 infection is increasing, the students continued protests over deferred exams reported by a famous Bangladeshi newspaper Bangla Tribune [35]. These may be another important factor for increasing the risk of depression and anxiety symptoms during post-panic period.

Moreover, female students found more anxious than the male and the result is comparable to other studies

Table 5: Degree of risk factors associated with student's depression and anxiety symptoms

\begin{tabular}{|c|c|c|c|c|}
\hline \multirow[t]{2}{*}{ Variables } & \multicolumn{2}{|l|}{ Depression } & \multicolumn{2}{|l|}{ Anxiety } \\
\hline & Unadjusted OR $(95 \% \mathrm{Cl})$ & Adjusted OR (95\% Cl) & Unadjusted OR $(95 \% \mathrm{Cl})$ & Adjusted OR $(95 \% \mathrm{Cl})$ \\
\hline \multicolumn{5}{|l|}{ Age } \\
\hline $17-21$ years & & & & \\
\hline $22-26$ years & $1.14(0.74-1.76)$ & $1.52(0.82-2.78)$ & $1.01(0.65-1.58)$ & $1.43(0.76-2.69)$ \\
\hline \multicolumn{5}{|l|}{ Gender } \\
\hline Male & & & & \\
\hline Female & $1.06(0.69-1.63)$ & $0.89(0.54-1.47)$ & $2.01(1.28-3.13)$ & $1.84(1.09-3.10)$ \\
\hline \multicolumn{5}{|l|}{ Family types } \\
\hline Nuclear & & & & \\
\hline Joint/Extended & $1.57(1.02-2.41)$ & $1.75(1.08-2.82)$ & $1.40(0.91-2.18)$ & $1.82(1.09-3.02)$ \\
\hline \multicolumn{5}{|l|}{ Place of residence } \\
\hline Rural & & & & \\
\hline Urban & $1.68(1.09-2.58)$ & $1.99(1.17-3.38)$ & $2.37(1.51-3.73)$ & $2.18(1.24-3.83)$ \\
\hline \multicolumn{5}{|c|}{ Family economic condition } \\
\hline \multicolumn{5}{|c|}{ Lower class } \\
\hline Lower middle class & $1.13(0.45-2.83)$ & $1.26(0.46-3.47)$ & $0.89(0.35-2.29)$ & $0.71(0.24-2.06)$ \\
\hline $\begin{array}{l}\text { Middle and upper } \\
\text { class }\end{array}$ & $1.00(0.42-2.40)$ & $1.17(0.42-3.32)$ & $0.87(0.56-2.12)$ & $0.51(0.17-1.55)$ \\
\hline \multicolumn{5}{|l|}{ Time period } \\
\hline Panic period & & & & \\
\hline Post-panic period & $1.13(0.74-1.72)$ & $1.10(0.74-1.87)$ & $0.98(0.63-1.51)$ & $0.94(0.57-1.54)$ \\
\hline
\end{tabular}


[9], [12], [14]. A study conducted by Shovo, remarked that female university students are more likely to suffer by depression and less prone to anxiety than male students [14]. However, the causes behind this outcome are still unknown. In addition, we also found urban students experiencing more depression and anxiety symptoms than the rural students which are comparable to other studies conducted among university student [8], [9], [14], [36], [37], [38]. This may be the fact that student's selfconsciousness about their career life [39]. In general, urban students are more conscious about their academic and job career life which resulted depression [40], [41].

One of the major limitation of this study is that the cross-sectional study was conducted using a Google-based questionnaire which may affect in the representativeness of our findings. A nationally representative longitudinal study would help to overcome the limitations, but it is time expensive, consuming and quite difficult to undertake in Bangladeshi context. The study found post-panic period as the vulnerable to university student's depression symptoms at $7 \%$ level of significant. The results could be more significant if there is possible to conduct the study with a sufficiently large sample size. To assess the student's depression and anxiety, we used two famous questionnaire tools (PHQ-9 and GAD-7) that are mostly psychological. However, there have also many other pandemic related factors that are responsible for depression and anxiety of the university students of Bangladesh.

\section{Conclusions}

Our study shows that university students experienced a higher degree of depression and anxiety symptoms during both panic and post-panic periods. Although the prevalence in each period was not statistically significant at $5 \%$ level, university students in Bangladesh were concerned because it interfered with their academic life. The government of Bangladesh and university authorities should move quickly to open all universities and public service commissions for taking incomplete exams and academic activities while adhering to health regulations. The government, university authorities, and parents should be encouraged to create a friendly academic environment for university students without imposing pressure on their future academic and working careers by providing pandemic response and recovery supports.

\section{Ethical Consent}

Formal approval (registration: MBSTU/ EC/2020/07) of this study was taken from the Department of Statistics, Mawlana Bhashani Science and Technology University, Santosh, Tangail-1902, Bangladesh. In accordance with the standards of Helsinki Declaration and its corresponding modifications or similar ethical principles, this study was carried out. The data were collected using an online survey where the informed consent was obtained from each of the students before starting the survey. Respondents then expressed their consent, after reading the aforementioned, to take part in the study by clicking either "Yes" or "No." Those who did not consent, by clicking "No" were not included the study.

\section{Availability of Data and Materials}

The data used to support the findings in this study are available from the corresponding author on reasonable request to meshbah037@gmail.com.

\section{Author's Contribution}

MMR, GKP and SN designed the concept of the study. MMR fixed the study design. MMR, MHC and MJU supervised the study. MMR, GKP tabulated and drafted the manuscript. MMR, MHC, SN and MJU edited and checked the draft for important intellectual context. All authors helped for finalizing the version to be submitted.

\section{Acknowledgment}

We want to acknowledge the students who helped in this study by responding the questionnaire.

\section{References}

1. Ahammed T, Anjum A, Rahman MM, Haider N, Kock R, Uddin MJ. Estimation of novel Coronavirus (COVID-19) reproduction number and case fatality rate: A systematic review and meta-analysis. Health Sci Rep. 2021;4(2):e274. https://doi. org/10.1002/hsr2.274

PMid:33977156

2. Rahman MM, Bhattacharjee B, Farhana Z, Hamiduzzaman M, Chowdhury MAB, Hossain MS, et al. Age-related risk factors and severity of SARS-CoV-2 Infection: A systematic review and meta-analysis. J Prev Med Hyg. 2021;62(2):E329. https://doi. org/10.15167/2421-4248/jpmh2021.62.2.1946 


\section{PMid:34604574}

3. Haque MF, Rahman MM, Alif SM, Akter E, Barua S, Paul GK et al. Estimation and prediction of doubling time for COVID-19 epidemic in Bangladesh: A modelling study of first 14 month's daily confirmed new cases and deaths. Glob Biosecur. 2021;3(2). https://doi.org/10.31646/gbio.91

4. World Health Organization. WHO Director-General's Opening Remarks at the Media Briefing on COVID-19-11 March 2020. WHO Director General's Speeches. Geneva: World Health Organization; 2020. p. 4.

5. Rossi R, Socci V, Pacitti F, Mensi S, Di Marco A, Siracusano A, et al. Mental health outcomes among healthcare workers and the general population during the COVID-19 in Italy. Front Psychol. 2020;11:608986. https://doi.org/10.3389/fpsyg.2020.608986 PMid:33363500

6. Savage MJ, James R, Magistro D, Donaldson J, Healy LC, Nevill M, et al. Mental health and movement behaviour during the COVID-19 pandemic in UK university students: Prospective cohort study. Ment Health Phys Act. 2020;19:100357. https:// doi.org/10.1016/j.mhpa.2020.100357

7. Ferdous MZ, Islam MS, Sikder MT, Mosaddek ASM, ZegarraValdivia JA, Gozal D. Knowledge, attitude, and practice regarding COVID-19 outbreak in Bangladesh: An online-based cross-sectional study. PLoS One. 2020;15(10):e0239254. https://doi.org/10.1371/journal.pone.0239254

PMid:33035219

8. Sifat RI. COVID-19 pandemic: Mental stress, depression, anxiety among the university students in Bangladesh. Int J Soc Psychiatry. 2021;67(5):609-10. https://doi. org/10.1177\%2F0020764020965995

PMid:33040666

9. Islam MA, Barna SD, Raihan H, Khan MN, Hossain MT. Depression and anxiety among university students during the COVID-19 pandemic in Bangladesh: A web-based crosssectional survey. PLoS One. 2020;15(8):e0238162. https://doi. org/10.1371/journal.pone.0238162

PMid:32845928

10. Islam MS, Ferdous MZ, Potenza MN. Panic and generalized anxiety during the COVID-19 pandemic among Bangladeshi people: An online pilot survey early in the outbreak. J Affect Disord. 2020;276:30-7. https://doi.org/10.1016/j. jad.2020.06.049 PMid:32697713

11. Safa F, Anjum A, Hossain S, Trisa TI, Alam SF, Rafi MA, et al. Immediate psychological responses during the initial period of the COVID-19 pandemic among Bangladeshi medical students. Child Youth Serv Rev. 2021;122:105912. https://doi. org/10.1016/j.childyouth.2020.105912 PMid:33390637

12. Faisal RA, Jobe MC, Ahmed O, Sharker T. Mental health status, anxiety, and depression levels of Bangladeshi University students during the COVID-19 pandemic. Int J Ment Health Addict. 2021;1-16. https://doi.org/10.1007\%2Fs11469-020-00458-y PMid:33424514

13. Rodríguez-Hidalgo AJ, Pantaleón Y, Dios I, Falla D. Fear of COVID-19, stress, and anxiety in university undergraduate students: A predictive model for depression. Front Psychol. 2020;11:591797.https://doi.org/10.3389\%2Ffpsyg.2020.591797 PMid:33224080

14. Shovo TE, Ahammed B, Khan B, Jahan N, Shohel TA, Hossain T, et al. Determinants of generalized anxiety, depression, and subjective sleep quality among university students during COVID-19 pandemic in Bangladesh. Sulaiman AI Habib Med J. 2021;3(1):27-35. https://doi.org/10.2991/dsahmj.k.210108.001

15. Bhuiyan AK, Sakib N, Pakpour AH, Griffiths MD, Mamun MA.
COVID-19-related suicides in Bangladesh due to lockdown and economic factors: Case study evidence from media reports. Int J Ment Health Addict. 2020;19:1-16. https://doi.org/10.1007/ s11469-020-00307-y

PMid:32427168

16. Mamun MA, Griffiths MD. A rare case of Bangladeshi student suicide by gunshot due to unusual multiple causalities. Asian J Psychiatr. 2020;49:101951. https://doi.org/10.1016/j. ajp. 2020.101951

PMid:32078949

17. World Health Organization. COVID-19 Morbidity and Mortality Weekly Update. Geneva: World Health Organization; 2020.

18. World Health Organization. Routine Immunization in Bangladesh set to Get Back on Track Amidst COVID-19 Pandemic and Massive Flooding. Genva: World Health Organization; 2020.

19. Islam A. Why Bangladeshis no longer fear the coronavirus. Germany: Deutsche Welle (DW); 2020.

20. Kroenke K, Spitzer RL, Williams JB, Lowe B. The patient health questionnaire somatic, anxiety, and depressive symptom scales: A systematic review. Gen Hosp Psychiatry. 2010;32(4):345-59. https://doi.org/10.1016/j.genhosppsych.2010.03.006 PMid:20633738

21. Rahman M, Hamiduzzaman M, Akter M, Farhana Z, Hossain M, Hasan M, et al. Frailty indexed classification of Bangladeshi older adults' physio-psychosocial health and associated risk factors-a cross-sectional survey study. BMC Geriatr. 2021;21(1):3. https:// doi.org/10.1186/s12877-020-01970-5 PMid:33402094

22. Paul GK, Rahman MM, Hamiduzzaman M, Farhana Z, Mondal SK Akter S, et al. Hypertension and its physio-psychosocial risks factors in elderly people: A cross-sectional study in North-Eastern region of Bangladesh. J Geriatr Cardiol. 2021;18(1):75-82. https://doi.org/10.11909/j.issn.1671-5411.2021.01.011 PMid:33613661

23. Rahman M, Begum M, Uddin M, Rahman M. Factors affecting health status of urban aged population: Evidence from sylhet, Bangladesh. Indian J Gerontol. 2018;32(1):103-18.

24. GardaWorld. Bangladesh: Government Extends Nationwide Lockdown Until. Bangladesh: GardaWorld; 2020.

25. Dhaka Tribune. Bangladesh to go Into Week-Long Hard Lockdown from April 14. Dhaka Tribune; 2021.

26. Shamsuddin K, Fadzil F, Ismail WS, Shah SA, Omar K Muhammad NA, et al. Correlates of depression, anxiety and stress among Malaysian University students. Asian J Psychiatr. 2013;6(4):318-23. https://doi.org/10.1016/j.ajp.2013.01.014 PMid:23810140

27. Tribune Report. National University Students Continue Protests Over Deferred Exam. Dhaka Tribune; 2021.

28. Islam MS, Sujan MS, Tasnim R, Sikder MT, Potenza MN, van Os J. Psychological responses during the COVID-19 outbreak among University students in Bangladesh. PLoS One. 2020;15:e0245083. https://doi.org/10.1371/journal. pone. 0245083

PMid:33382862

29. Anjum A, Hossain S, Hasan MT, Alin SI, Uddin ME, Sikder MT. Depressive symptom and associated factors among school adolescents of urban, semi-urban and rural areas in Bangladesh: A scenario prior to COVID-19. Front Psychiatry. 2021;12:708909. https://doi.org/10.3389/fpsyt.2021.708909 PMid:34650452

30. Lu P, Yang L, Wang C, Xia G, Xiang H, Chen G, et al. Mental health of new undergraduate students before and after COVID-19 in China. Sci Rep. 2021;11:18783. https://doi. org/10.1038/s41598-021-98140-3

31. Al Mamun F, Hosen I, Misti JM, Kaggwa MM, Mamun MA 
Mental disorders of bangladeshi students during the COVID-19 pandemic: A systematic review. Psychol Res Behav Manag. 2021;14:645-54. https://doi.org/10.2147/PRBM. S315961

PMid:34104010

32. Li Z, Qiu Z. How does family background affect children's educational achievement? evidence from contemporary China. J Chin Soc. 2018;5:13. https://doi.org/10.1186/ s40711-018-0083-8

33. Rizvi F, Qureshi A, Rajput AM, Afzal M. Prevalence of depression, anxiety and stress (by DASS scoring system) among medical students in Islamabad, Pakistan. Br J Med Med Res 2015;8(1):69-75.

34. Kumari R, Langer B, Jandial S, Gupta R, Raina SK, Singh P. Psycho-social health problems: Prevalence and associated factors among students of professional colleges in Jammu. Indian J Community Health. 2019;31(1):43-9.

35. Lun KW, Chan CK, Ip PK, Ma SY, Tsai WW, Wong CS, et al. Depression and anxiety among university students in Hong Kong. Hong Kong Med J. 2018;24(5):466-72. https://doi. org/10.12809/hkmj176915

PMid:30245480

36. Kulsoom B, Afsar NA. Stress, anxiety, and depression among medical students in a multiethnic setting. Neuropsychiatr Dis Treat. 2015;11:1713-22. https://doi.org/10.2147/NDT.S83577

\section{PMid:26213470}

37. Bayram N, Bilgel N. The prevalence and socio-demographic correlations of depression, anxiety and stress among a group of university students. Soc Psychiatry Psychiatr Epidemiol. 2008;43(8):667-72. https://doi.org/10.1007/s00127-008-0345-x PMid:18398558

38. Abdallah AR, Gabr HM. Depression, anxiety and stress among first year medical students in an Egyptian public university. Int Res J Med Med Sci. 2014;2(1):11-9.

39. Lovell GP, Nash K, Sharman R, Lane BR. A cross-sectional investigation of depressive, anxiety, and stress symptoms and health-behavior participation in Australian university students. Nursing Health Sci. 2015;17(1):134-42.

40. Beiter R, Nash R, McCrady M, Rhoades D, Linscomb M, Clarahan $\mathrm{M}$, et al. The prevalence and correlates of depression, anxiety, and stress in a sample of college students. J Affect Disord. 2015;173:90-6. https://doi.org/10.1016/j.jad.2014.10.054 PMid:25462401

41. Marzo RR, Vinay V, Bahari R, Chauhan S, Ming DA Fernandez SF, et al. Depression and anxiety in Malaysian population during third wave of the COVID-19 pandemic. Clin Epidemiol Glob Health. 2021;12:100868. https://doi. org/10.1016/j.cegh.2021.100868

PMid:34549098 